\title{
Cell-Specific Expression of Fibronectin in Adult and Developing Rabbit Lung
}

\author{
ROBERT A. SINKIN, RAYMOND S. SANDERS, ${ }^{1}$ STUART HOROWITZ, ${ }^{2}$ JACOB N. FINKELSTEIN, \\ AND MICHAEL B. LOMONACO \\ University of Rochester, Department of Pediatrics (Neonatology) and the Strong Children's \\ Research Center
}

\begin{abstract}
Fibronectin (FN), a glycoprotein component of the extracellular matrix, plays a role in tissue morphogenesis and tissue-specific differentiation through its effects on cell adhesion, cell shape, and cytoskeletal organization. Immunohistochemistry has been used to show that during lung development FN deposition changes, yet the cell-specific sites of pulmonary FN synthesis have not been determined. Because cellular FN synthesis is reflected by FN mRNA abundance, we performed in situ hybridizations to identify pulmonary tissue with the capacity to synthesize FN. Both in situ mRNA hybridization and immunohistochemical staining were performed on tissue sections from lungs of adults and late gestation fetal and neonatal rabbits. In adults, FN transcripts and immunostaining were clearly seen in endothelial cells, smooth muscle cells, and chondrocytes. During lung development, FN transcripts were virtually ubiquitous except in airway epithelium. There was a gradual decrease in FN mRNA abundance with advancing fetal age, but low levels of FN mRNA persisted in neonatal and adult lungs. In contrast,
\end{abstract}

\section{ABSTRACT}

parenchymal immunostaining increased throughout fetal development and remained elevated in the newborn. FN immunostaining was lower in adult lung. In all tissues examined, airway epithelial cells contained no FN transcripts above background. However, immunostaining was detected in airway basement membrane zones and on luminal surfaces of some epithelial cells. The lack of FN transcripts in airway epithelial cells suggests that FN synthesis does not normally occur in this cell type and that its associated FN immunostaining is from another source. The colocalization of FN mRNA and protein in pulmonary endothelial cells, smooth muscle cells, and chondrocytes in adults strongly suggests that these cells are sites of FN synthesis. (Pediatr Res 37: 189-195, 1995)
FN, fibronectin
Abbreviations
ECM, extracellular matrix
PBF, phosphate-buffered formalin

$\mathrm{FN}$ is a large glycoprotein that exists as an insoluble form in the ECM and as a soluble form in plasma (1). The protein consists of two near-identical subunits joined by disulfide bonds near the carboxy-termini. Each subunit is composed of a series of globular domains, each of which is specialized for binding to other molecules or cells. These binding properties allow FN to participate in tissue morphogenesis by affecting cell adhesion, cell shape, and cytoskeletal organization (2). Independent lines of investigation have demonstrated that FN is required for the formation of the mesoderm in the vertebrate embryo and has an essential role in neural crest cell migration $(3,4)$. The expression of FN is prominent during early human fetal microvasculature development and diminishes with maturation (5). FN levels increase during periods of tissue mor-

Received March 31, 1994; accepted August 22, 1994.

Correspondence: Robert A. Sinkin, M.D., University of Rochester, Department of Pediatrics (Neonatology), 601 Elmwood Ave., Box 651, Rochester, NY 14642.

Supported by National Institutes of Health SCOR Grant HL-36543 and by grants from the March of Dimes (R.A.S.) and the Strong Children's Research Center (R.A.S.).

${ }^{1}$ Current address: New York University Medical Center, Department of Pediatrics Neonatal Program, 550 First Ave., New York, NY 10018.

${ }^{2}$ Current address: CardioPulmonary Research Institute, Suite 503, Winthrop-University Hospital, 222 Station Plaza, N. Mineola, NY 11501. phogenesis, perhaps providing positional information for regulating the differentiation and migration of cells (6).

$\mathrm{FN}$ in lung has been studied by immunohistochemical staining (7-10). Local concentrations of FN change during development (9-12). FN levels peak during periods of maximal cell proliferation, secondary septation, and tissue remodeling $(9,10,12)$. It has been speculated that increased concentrations of FN in the ECM might directly influence the hyperplasia of the fetal lung epithelium and the differentiation of alveolar epithelial cells (9). Because FN is synthesized and secreted from nonpulmonary organs $(1,2)$ and is a relatively abundant plasma protein (1), the contribution of pulmonary cell-specific FN synthesis to total lung tissue FN is not yet known. To examine the possibility that $\mathrm{FN}$ expression is developmentally regulated in lung, in situ hybridization and immunohistochemical staining were used on tissue sections of developing and adult rabbit lung.

\section{METHODS}

Animals and tissue preparation. New Zealand White rabbit timed-pregnant does and adult males were killed by the administration of sodium pentobarbital $(80 \mathrm{mg} / \mathrm{kg})$ into an ear 
vein. After hysterotomy, fetal rabbits were immediately immersed in ice-cold saline. Fetal lungs were dissected free and placed in $10 \%$ PBF. Newborn rabbits were killed with an intraperitoneal injection of sodium pentobarbital $(80 \mathrm{mg} / \mathrm{kg})$. For newborns and adult males, the trachea was isolated and cannulated with a 22-gauge angiocatheter or 2.5 French endotracheal tube, respectively, and instilled with PBF under 19.6 mbar $\left(20 \mathrm{~cm} \mathrm{H}_{2} \mathrm{O}\right)$ pressure. The lungs were then dissected free and placed in a fixation chamber in which PBF was continuously instilled at 19.6 mbar pressure for $2 \mathrm{~h}$. The lobes were then placed in fresh PBF. All tissue was embedded in paraffin. Lung tissue sections ( $4 \mu \mathrm{m}$ ) were mounted on 3-aminopropyltriethoxysilane-treated slides $(13,14)$. Lung tissue was obtained from rabbit fetuses at $21,25,27$, and $31 \mathrm{~d}$ gestation, from d-1 newborn animals, and from adult males.

In situ hybridization. A rabbit FN probe was used for these studies (13). Single-stranded ${ }^{3} \mathrm{H}$-labeled FN complementary RNA probes (sense and antisense) were synthesized using T7 and SP6 polymerases, respectively. Paraffin-embedded sections were deparaffinized in xylene, hydrated by passage through a graded ethanol series, and incubated for $30 \mathrm{~min}$ in $100 \mathrm{mM}$ Tris- $\mathrm{HCl}$ ( $\mathrm{pH} \mathrm{8.0)}$ containing $50 \mathrm{mM}$ ethylenediaminetetraacetic acid and $1 \mu \mathrm{g} / \mathrm{mL}$ of Proteinase $\mathrm{K}$ (BRL, Gaithersburg, MD) at $37^{\circ} \mathrm{C}$. The slides were briefly washed in distilled water, treated in $0.1 \mathrm{M}$ triethanolamine- $\mathrm{HCl}(\mathrm{pH} 8.0)$, and then placed in fresh $0.1 \mathrm{M}$ triethanolamine containing $0.25 \%$ acetic anhydride for $10 \mathrm{~min}$ at room temperature. The slides were then processed for in situ hybridization and autoradiography, as previously described (13).

Immunohistochemistry. Goat anti-rabbit FN antibody, IgG fraction (Cappel Research Products, Durham, NC), was diluted to $1: 500$ in TBS (25 mM Tris, $140 \mathrm{mM} \mathrm{NaCl}, 2.6 \mathrm{mM} \mathrm{KCl} \mathrm{pH}$ 7.4) and 3\% BSA (Sigma Chemical Co., St. Louis, MO). For control slides, this same antibody dilution was preabsorbed with $200 \mu \mathrm{g} / \mathrm{mL}$ of rabbit FN (Organon Teknika, West Chester, PA) overnight at $4^{\circ} \mathrm{C}$, and centrifuged at $300 \times g$ before use. Tissue sections were deparaffinized and hydrated as described above. The slides were digested briefly in $0.1 \%$ trypsin, $0.1 \% \mathrm{CaCl}$, and $20 \mathrm{mM}$ Tris- $\mathrm{HCl}(\mathrm{pH} 7.8)$ for $5 \mathrm{~min}$, followed by a 5 -min wash in distilled water. To quench endogenous tissue peroxidase activity, slides were then placed in methanol containing $0.3 \% \mathrm{H}_{2} \mathrm{O}_{2}$ for $30 \mathrm{~min}$. After a rinse in distilled water, the slides were placed in a solution of TBS with $0.02 \%$ Triton-X 100 (Sigma Chemical Co.) for $10 \mathrm{~min}$, followed by a 10-min wash in TBS. Slides were blotted dry to remove excess TBS, and each section was encircled using a Papanicolaou pen (Research Products International Corp., Mount Prospect, IL). Two hundred $\mu \mathrm{L}$ of TBS containing 3\% BSA were placed on each slide and allowed to incubate for $30 \mathrm{~min}$ at room temperature in a humidified chamber. The slides were blotted, and 200 $\mu \mathrm{L}$ of antibody were placed on each slide. After overnight incubation, the slides were washed in TBS for $10 \mathrm{~min}$, individually blotted, and incubated with $200 \mu \mathrm{L}$ of biotinylated rabbit anti-goat antibody (1:200 dilution) (Cappel Research Products, Durham, NC) in a humidified chamber for $1 \mathrm{~h}$ at room temperature. The slides were washed in TBS buffer for 10 min, blotted, and incubated with $200 \mu \mathrm{L}$ of Vectastain $\mathrm{ABC}$ reagent (Vector Laboratories, Burlingame, $\mathrm{CA}$ ) for $1 \mathrm{~h}$ at room temperature in a humidified chamber. The slides were washed twice in TBS buffer for $10 \mathrm{~min}$, blotted, and incubated with 200 $\mu \mathrm{L}$ of diaminobenzidine tetrahydrochloride substrate (Sigma Chemical Co.) for $10 \mathrm{~min}$ at room temperature. The slides were rinsed in distilled water for $5 \mathrm{~min}$ and counterstained with $0.01 \%$ methylene blue. In addition to preabsorbing the primary antibody with FN, control slides were also prepared in which either the primary or both the primary and secondary antibodies were omitted.

\section{RESULTS}

Immunohistochemical staining and in situ hybridization were performed on lung sections from fetal, newborn, and adult rabbits to determine the cell-specific distribution of FN mRNA and protein. The presence or absence of FN immunostaining and FN mRNA transcripts are summarized in Table 1 for all developmental stages studied and for freshly isolated and cultured cells as described below (13, 15-17).

Figure 1 shows FN immunostaining in adult, fetal, and newborn lung. Several controls were used for the immunohistochemical assays. No immunostaining was observed when either the primary antibody (Fig. $1 b$ and $d$ ) or the secondary antibody (results not shown) was omitted. Also, specific staining was eliminated by preabsorption of the antibody by purified rabbit serum-derived FN (results not shown). A general finding of our study was that FN protein was found at modest levels in the adult lung and in pseudoglandular lung but appeared to increase during the fetal period examined and remained elevated in the $\mathrm{d}-1$ newborn lung (Fig. $1 e-h$ ). In contrast to adult lungs, saccular and early alveolar lungs (Fig. $1 g$ and $h$, respectively) had markedly elevated levels of $\mathrm{FN}$ immunostaining.

In adult lung, positive alveolar intraseptal immunostaining was usually observed (Fig. 1a), although this level of resolution was not sufficient to identify cell types. FN immunostaining was always prominent in the cells composing vessel walls (Fig. 1a). Under high magnification (results not shown), these cells had morphologic characteristics of endothelial and

Table 1. Cell-specific fibronectin $m R N A$ and protein distribution as determined by in situ hybridization and immunohistochemistry

\begin{tabular}{|c|c|c|}
\hline Cell type & FN mRNA & FN protein \\
\hline Vascular smooth muscle & ш & $\mathbf{\square}$ \\
\hline Airway smooth muscle & $\mathbf{u}$ & $\mathbf{\square}$ \\
\hline Endothelium & घ & $\mathbf{\square}$ \\
\hline Chondrocytes & - & $\mathbf{\theta}$ \\
\hline Airway epithelium & $\square$ & 凶 \\
\hline Mesenchyme* & $\mathbf{a}$ & $\mathbf{a}$ \\
\hline Alveolar macrophages $\dagger$ & घ & a \\
\hline Fibroblastsł & - & $\mathbf{\square}$ \\
\hline Type II cells§ & - & $\mathbf{\square}$ \\
\hline
\end{tabular}

, readily detectable in many cells; $\mathbf{\square}$, detectable in some cells; $囚$, luminal and basal surface staining only, cytoplasmic staining barely detectable in limited numbers of cells; $\square$, not present under conditions examined.

* This also includes airway supporting stroma that may contain fibroblasts, smooth muscle, and capillary endothelial cells.

$\dagger$ Includes freshly isolated cells and those observed in situ in alveolar spaces (13).

$\$$ Cultured rabbit fetal fibroblasts [R9ab, American Type Culture Collection (ATCC)] (15).

$\S$ Freshly isolated and cultured adult rabbit type II cells $(16,17)$. 

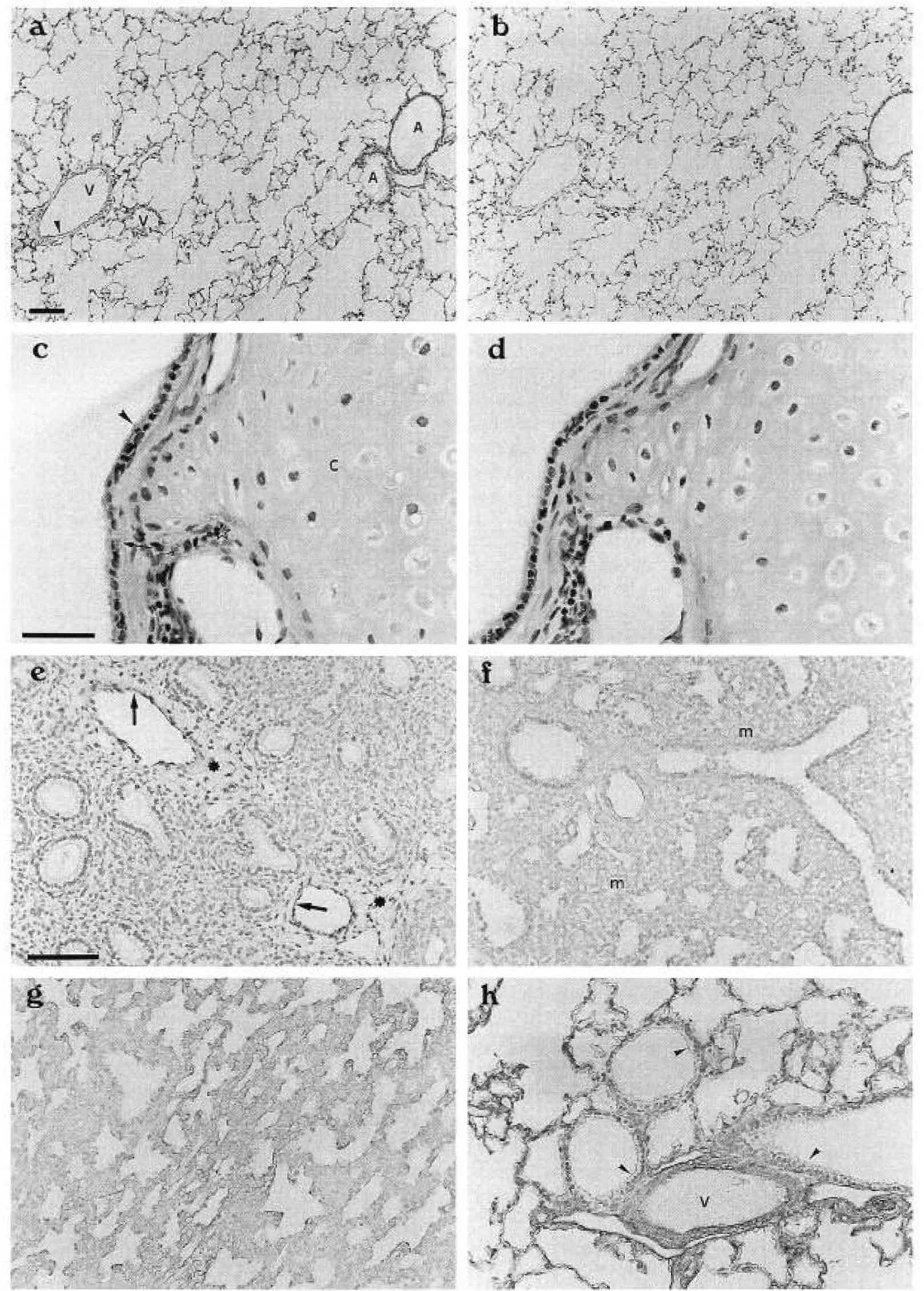
smooth muscle cells. Figure $1 c$ shows a high-power view of a conducting airway and an associated cartilage plate. FN was detected above background on the luminal surfaces of some epithelial cells. FN was also occasionally seen at low levels in the basement membrane zone (Fig. 1c) of the epithelium of large airways and occasionally in the supporting musculature (not seen in this section). In no case was FN immunostaining observed within the cytoplasm of airway epithelial cells. Chondrocytes and perichondrocytes were usually stained, but not as prominently as vessels.

FN immunostaining was detected at modest levels in endothelium and connective tissue of developing pulmonary vessels and at low levels in the mesenchyme of d-21 pseudoglandularstage fetal lungs (Fig. 1e). During the canalicular period, $\mathrm{FN}$ in mesenchyme and connective tissue was more evident (Fig. 1f). By d 27, during the saccular stage, a time of mesenchymal condensation and alveolarization, $\mathrm{FN}$ immunostaining was markedly but not uniformly increased (Fig. 1g). FN immunostaining was most intense in the d-1 neonatal lung, with prominent staining of large vessels and alveolar septa (Fig. 1g). FN was apparently ubiquitous in neonatal rabbit lungs and was seen along the apical and basal surfaces of some epithelium (Fig. 1h, arrows) but as in adult lung epithelium, was never clearly identified within the cytoplasm of these cells. FN immunostaining was consistently detected in smooth muscle cells lining large blood vessels and in endothelial cells at all ages studied (Fig. $1 e$ and $h$ ).

Similar lung sections were used for in situ hybridization. Figure $2 a$ and $b$ shows dark-field microscopic images of autoradiograms of adult rabbit lung sections hybridized with antisense and sense (control) probes, respectively. In contrast to the low background obtained with the sense probe, the antisense probe showed FN transcripts in cells of alveolar septa and vessel wall cells. Airway epithelial cells were devoid of signal, although some grains were evident in some underlying support cells that had morphologic characteristics of smooth muscle cells (results not shown). FN mRNA was clearly identified within chondrocytes of cartilage supporting conducting airways (Fig. 3a). Endothelial cells of large vessels were often prominently labeled (Fig. $3 b$ ), as were the smooth muscle cells of vessel walls (results not shown).

FN mRNA appeared to decrease throughout the developmental period examined. Although $\mathrm{FN}$ transcripts were relatively abundant in the d-21 and d-25 fetal lung (Fig. $2 c$ and $d$ ), there was an apparent decrease in FN mRNA accumulation in d-27 (Fig. 2e) and d-31 (results not shown) fetal lung. The level and pattern of FN mRNA accumulation in d-1 neonatal lung was more similar to adult lung than to fetal lungs studied. As seen in adults, FN mRNA was found to accumulate in the endothelium and musculature of large airways (Fig. $2 f$ ). FN transcripts were clearly found over mesenchyme, but cellspecific identification was not possible. No FN mRNA was found within epithelium at any age studied. Chondrocytes and presumed smooth muscle cells of developing conducting airways were occasionally observed to contain FN mRNA, but these tissues were infrequently observed.

\section{DISCUSSION}

Previous studies have shown FN accumulation in developing lung tissue, but inasmuch as $\mathrm{FN}$ is a secreted protein and is found in circulation, the contribution of lung tissue to pulmonary FN has not been addressed. The results of this study show that not only are FN transcripts present in lung, but also the pattern of FN mRNA accumulation is developmentally regulated. We also provide evidence for colocalization of FN protein and mRNA. Taken together, the simplest interpretation of these observations is that FN is synthesized in adult and developing lung. However, our observations are also consistent with the notion that pulmonary $\mathrm{FN}$ is probably also derived from plasma, synthesized in the liver. We used a polyclonal antibody to rabbit FN that does not distinguish plasma from cellular FN. Previously, Kuhn et al. (18) used antibodies specific for cellular FN and found that much FN in normal human adult lung has its origin in plasma. Significantly, we detected FN mRNA in several cell types by in situ hybridization. At least three of these cell types-endothelial cells of large vessels, chondrocytes of tracheal cartilage, and smooth muscle-were identifiable on the basis of histologic examination.

FN in human bronchopulmonary lavage fluid (19) could be derived from airway epithelium or alveolar macrophages. Alveolar macrophages are a known source of FN (20) whose synthesis is thought to be controlled by steady state levels of mRNA (21). In this study and in others (13), both a low level of FN immunostaining and mRNA were seen in alveolar macrophages (not shown). In culture, bronchial epithelial cells demonstrate a capacity to synthesize FN (22), suggesting they are a potential in vivo source of FN. We detected weak FN immunostaining in small numbers of fetal, neonatal, and adult airway epithelial cells. Somewhat stronger immunostaining was reported using the same FN antibody (9), perhaps as a result of our using paraffin-embedded tissue. Our methods of tissue fixation and embedding were

\footnotetext{
Figure 1. FN immunostaining in rabbit lung. These sections were simultaneously processed for immunohistochemical detection of FN. $a$ and $b$, Serial sections of adult lung with $(a)$ and without $(b)$ primary antibody. Smooth muscle $($ star $)$ and endothelium (arrowhead) of vessels $(V)$ were prominently stained. Alveolar septa were immunopositive, but the epithelial cells of larger connecting airways $(A)$ were not. Bar $=100 \mu \mathrm{m}$. $c$ and $d$, Proximal airway and underlying cartilage with $(c)$ and without $(d)$ primary antibody. Bronchial epithelial cells showed luminal staining (arrowhead) and some basal staining (arrow) but virtually no cytoplasmic staining. Chondrocytes of cartilage $(C)$ and perichondrial cells (star) were stained in this section. Bar $=50 \mu \mathrm{m} . e-h$, Developing lung. Lung sections from fetal d 21, 25, and 27 (e,f, and $g$, respectively) and neonatal d $1(h)$. Fetal 21-d glandular stage lung $(e)$ showed FN immunostaining in endothelial cells (arrows) and connective tissue (asterisks) of pulmonary vessels. Fetal 25-d canalicular stage lung $(f)$ had more prominent mesenchymal staining $(m)$ associated with developing vessels. FN immunostaining was more apparent in samples showing alveolarization and continued vascularization of the fetal $27-\mathrm{d}$ saccular stage lung $(g)$. Intense staining of muscle, endothelium, and connective tissue surrounding large vessels $(V)$ of $d-1$ neonatal lung $(h)$ was often seen. Luminal surfaces of large airways (arrowheads) and alveolar septa are prominently stained. Bar $=100 \mu \mathrm{m}$ for panels $e-h$.
} 

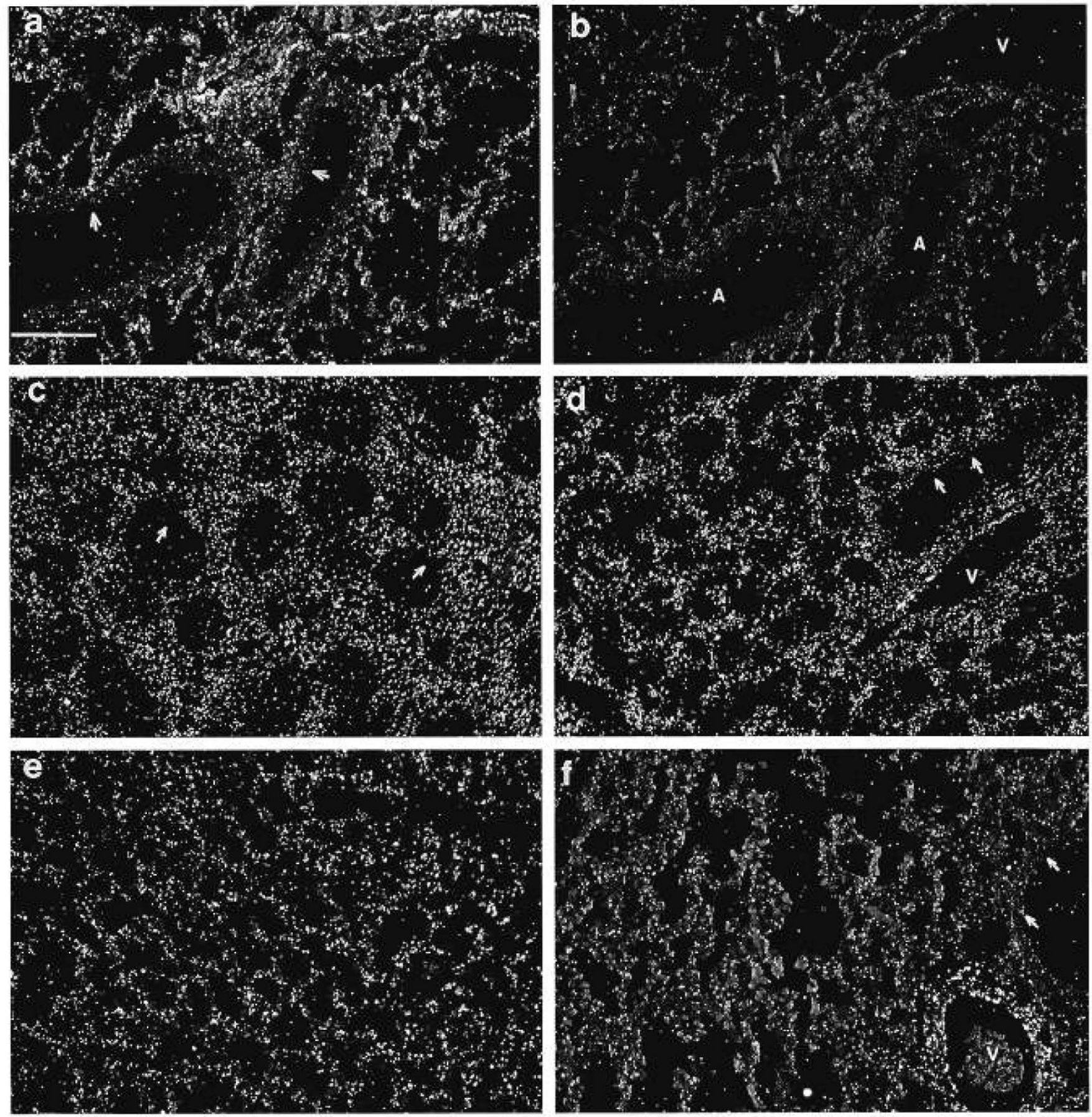

Figure 2. In situ hybridizations of FN mRNA in rabbit lungs. Panels $a-f$ are dark-field images. $a$, Anti-sense complementary RNA (see Methods) detects abundant FN mRNA in endothelial, muscle, and alveolar septal cells. $b$, Control (sense) complementary RNA was used to probe a serial section of $a$. The paucity of grains in $b$ is an indication of the specificity of the probe. In adults, airway epithelium is devoid of FN mRNA (arrows), whereas endothelial and muscle cells of vessels contain abundant levels of FN mRNA. For clarity, large airways $(A)$ and a large vessel $(V)$ are labeled in $b . c-f$, FN in situ hybridization of fetal d-21, -25 , and -27 lungs $(c, d$, and $e$, respectively) and $\mathrm{d}-1$ neonatal lungs $(f)$. FN mRNA is detected in mesenchyme and vessel walls $(V)$ but not in epithelial cells lining developing airways (arrows). Bar $=100 \mu \mathrm{m}$.

selected to preserve mRNA as well as protein, and immunoreactivity might have been compromised in airway epithelium. Interestingly, Roman and McDonald (10) detected FN immunostaining only within larger airway epithelial cells of alveolar-stage paraffin-embedded mouse lung sections. Because FN mRNA was not detected in airway epithelium under the conditions examined, it seems unlikely that airway epithelium is a site of significant pulmonary FN synthesis. The associated luminal and epitheliummesenchyme interface staining that we observed is probably FN synthesized by other cells.

Alveolar type II cells have also been shown to synthesize FN in vitro (23). We previously observed FN mRNA in a small percentage of freshly isolated, adult rabbit type II pneumocytes (16). We have also observed high levels of FN mRNA in type II cells ex vivo $(16,17)$ accompanying in vitro phenotypic 

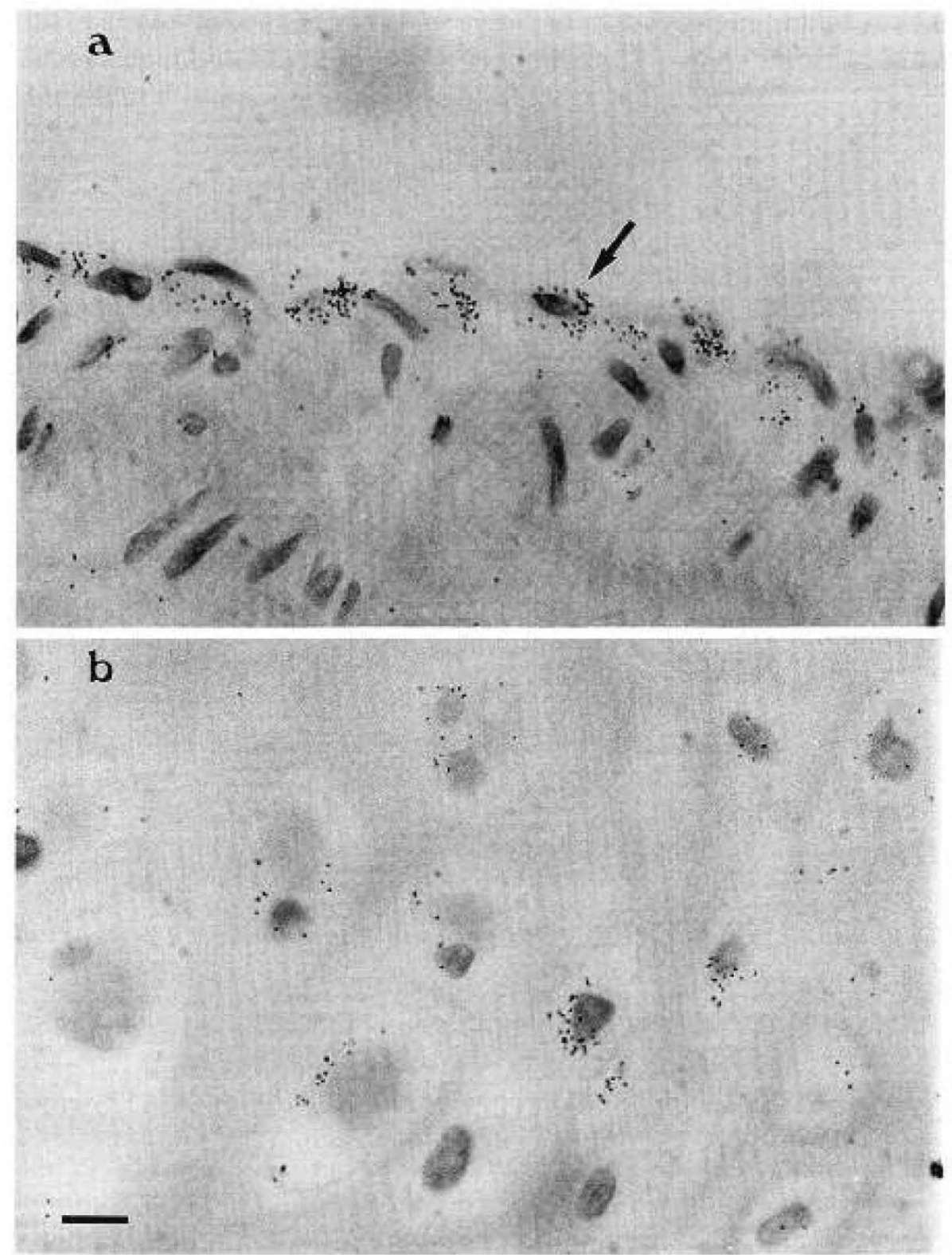

Figure 3. FN mRNA in endothelial cells and chondrocytes. $a$, In situ hybridization of FN mRNA in endothelial cells (arrow) of an adult rabbit pulmonary arterial blood vessel. Bar $=10 \mu \mathrm{m} . b$, In situ hybridization of FN mRNA of adult rabbit airway cartilage.

changes. These cell culture studies probably demonstrate the potential for type II pneumocytes to synthesize FN but might not reflect normal in vivo behavior. In tissue sections, type II cells cannot be identified at the light microscopic level without cell-specific markers. In our study, however, there was no pattern of FN mRNA seen that could even suggest its accumulation in type II cells, such as message-positive cells in alveolar corners.

In a previous study of developing rabbit lung (9), both FN immunostaining and extractable lung $\mathrm{FN}$ protein were increased during the period of increased vascularization and remained elevated until at least $2 \mathrm{~d}$ postpartum. In the current study, we show elevated rabbit lung FN mRNA before the period of increased vascularization, i.e. before maximal FN immunostaining is achieved. FN expression is thought to be controlled at the transcriptional level (24). Interestingly, FN transcripts appear most abundant during the pseudoglandular period, the fetal stage with the least immunostaining. This suggests that, in the developing rabbit lung, posttranscriptional mechanisms might regulate the accumulation of $\mathrm{FN}$ protein, or simply that protein synthesis is lagging. Alternatively, immunostaining might require accumulation of FN protein above a threshold concentration under the conditions used.

The signaling of ECM proteins, including FN, to the epithelium occurs via integrin receptors. Integrins are transmembrane adhesion receptors whose binding of specific ECM proteins promotes cell adhesion or migration and results in the generation of intracellular signals that participate in the control of proliferation and differentiation $(25,26)$. Although not completely understood, the mechanism of signal transduction is likely to depend on the ability of the cytoplasmic segments of integrins to interact with both the cytoskeleton and intracellular signaling molecules (27-30). The FN complementary RNA probe used in this study will not distinguish between mRNA 
splice variants that might exist in the lung. These variants may be important in cellular differentiation and migration by specifying integrin-matrix protein interactions (10).

In summary, the use of in situ hybridization and immunohistochemistry demonstrated that pulmonary $\mathrm{FN}$ is derived both from pulmonary and nonpulmonary sources and that the accumulation of FN mRNA is regulated in developing lung tissue in a cell-specific manner.

\section{REFERENCES}

1. Mosher DF 1984 Physiology of fibronectin. Annu Rev Med 35:561-575

2. Hynes R 1985 Molecular biology of fibronectin. Annu Rev Cell Biol 1:67-90

3. Thiery JP, Duband JL, Tucker GC 1985 Cell migration in the vertebrate embryo: role of cell adhesion and tissue environment in pattern formation. Annu Rev Cell Biol 1:91-113

4. Duband JL, Tucker GC, Poole TJ, Vincent M, Aoyama H, Thiery JP 1985 How do the migratory and adhesive properties of the neural crest govern ganglia formation in the avian peripheral nervous system? J Cell Biochem 27:189-203

5. Glukhova MA, Frid MG, Shekhonin BV, Balabanov YV, Koteliansky VE 1990 Expression of fibronectin variants in vascular and visceral smooth muscle cells in development. Dev Biol 141:193-202

6. Roman J, McDonald JA 1991 Potential role of RGD-directed integrins in mammalian lung branching morphogenesis. Development 112:551-558

7. Gil J, Martinez-Hernandez A 1984 The connective tissue of the rat lung: electron immunohistochemical studies. J Histochem Cytochem 32:230-238

8. Takusagawa K, Asoo N, Sato T, Nagai H, Motomiya M, Konno K 1986 Immunoelectron microscopic observations on the localization of fibronectin in normal human lung. Tohoku J Exp Med 150:209-223

9. Snyder JM, O'Brien JA, Rodgers HF 1987 Localization and accumulation of fibronectin in rabbit fetal lung tissue. Differentiation 34:32-39

10. Roman J, McDonald JA 1992 Expression of fibronectin, the integrin $\alpha 5$, and $\alpha$-smooth muscle actin in the heart and lung development. Am J Respir Cell Mol Biol $6: 472-480$

11. Chen WT, Chen JM, Mueller SC 1986 Coupled expression and colocalization of $140 \mathrm{~K}$ cell adhesion molecules, fibronectin, and laminin during morphogenesis and cytodifferentiation of chick lung cells. J Cell Biol 103:1073-1090

12. Plumb DJ, Dubaybo BA, Thet LA 1987 Changes in lung tissue fibronectin content and synthesis during postnatal lung growth. Pediatr Pulmonol 3:413-419

13. Sinkin RA, LoMonaco MB, Finkelstein JN, Watkins RH, Cox C, Horowitz S 1992 Increased fibronectin mRNA in alveolar macrophages following in vivo hyperoxia. Am J Respir Cell Mol Biol 7:548-555

14. Angerer LM, Stoler MH, Angerer RC 1987 In situ hybridization with RNA probes: an annotated recipe. In: Valentino $\mathrm{KL}$, Eberwine JH, Barchas JD (eds) In Situ
Hybridization: Applications to Neurobiology. Oxford University Press, New York, pp 42-70

15. Sinkin RA, LoMonaco MB 1990 Response of fibroblast and macrophage fibronectin mRNA to hyperoxia. J Cell Biochem 14(suppl A):158(abstr)

16. Sinkin RA, Horowitz S, LoMonaco MB, Kramer CM, Watkins RH, Rubin P, Finkelstein JN 1992 Fibronectin gene expression in rabbit alveolar macrophages and type II pneumocytes during in vivo hyperoxia- or radiation-induced injuries. Am Rev Respir Dis 145:829A(abstr)

17. Sinkin RA, Finkelstein JN, Kramer CM, LoMonaco MB, Watkins RH, Horowitz S 1991 Re-programming of type II pneumocyte gene expression in cell culture. Am Rev Respir Dis 148:305A(abstr)

18. Kuhn C, Boldt J, King TE, Crouch EC, Vartio T, McDonald JA 1989 An immunohistochemical study of architectural remodeling and connective tissue synthesis in pulmonary fibrosis. Am Rev Respir Dis 140:1693-1703

19. Rennard SI, Crystal RG 1981 Fibronectin in human bronchopulmonary lavage fluid. $\mathrm{J}$ Clin Invest 69:113-122

20. Villiger B, Kelley DG, Engleman W, Kuhn III C, McDonald JA 1981 Human alveolar macrophage fibronectin: synthesis, secretion, and ultrastructural localization during gelatin-coated latex particle binding. J Cell Biol 90:711-720

21. Yamauchi K, Martinet Y, Crystal RG 1987 Modulation of fibronectin gene expression in human mononuclear phagocytes. J Clin Invest 80:1720-1727

22. Shoji S, Rickard KA, Ertl RF, Robbins RA, Linder J, Rennard SI 1989 Bronchial epithelial cells produce lung fibroblast chemotactic factor: fibronectin. Am J Respir Cell Mol Biol 1:13-20

23. Sage H, Farin FM, Striker GE, Fisher AB 1983 Granular pneumocytes in primary culture secrete several major components of the extracellular matrix. Biochemistry 22:2148-2155

24. Roman J, McDonald JA 1991 Fibronectins. In: Crystal RH (ed) The Lung. Raven Press, New York, pp 399-411

25. Chen WT, Hasegawa E, Hasegawa T, Weinstock C, Yamada KM 1985 Development of cell surface linkage complexes in cultured fibroblasts. J Cell Biol 100:1103-1114

26. Damsky CH, Knudsen KA, Bradley D, Buck CA, Horowitz AF 1985 Distribution of the cell substratum attachment (CSAT) antigen on myogenic and fibroblastic cells in culture. J Cell Biol 100:1528-1539

27. Schwartz MA, Lechene C, Ingber DE 1991 Insoluble fibronectin activates the $\mathrm{Na} / \mathrm{H}$ antiporter by clustering and immobilizing integrin $\alpha_{5} \beta_{1}$, independent of cell shape. Proc Natl Acad Sci USA 88:7849-7853

28. Guan JL, Trevithick JE, Hynes RO 1991 Fibronectin-integrin interaction induces tyrosine phosphorylation of a $120 \mathrm{kD}$ protein. Cell Regul 2:951-964

29. Kornberg LJ, Hearp HS, Turner CE, Prockop C, Juliano RL 1991 Signal transduction by integrins: increased protein tyrosine phosphorylation caused by clustering of $\beta_{1}$ integrins. Proc Natl Acad Sci 88:8392-8396

30. Guan JL, Shalloway D 1992 Regulation of focal adhesion-associated protein tyrosine kinase by both cellular adhesion and oncogenic transformation. Nature 358: $690-692$ 